\title{
STUDY OF THE MECHANISM OF NITROPHENOLS SORPTION ON EXPANDED PERLITE - EQUILIBRIUM AND KINETICS MODELLING
}

\author{
Zvezdelina Yaneva $^{1,2 *}$, Bogdana Koumanova ${ }^{1}$, Nedyalka Georgieva ${ }^{2}$ \\ ${ }^{1}$ Department of Chemical Engineering, University of Chemical Technology and Metallurgy, \\ 8 Kliment Ohridski, 1756 Sofia, Bulgaria \\ ${ }^{2}$ Chemistry Unit, Department of Pharmacology, Animal Physiology and Physiological \\ Chemistry, Faculty of Veterinary Medicine, Trakia University, \\ Students Campus, 6000 Stara Zagora, Bulgaria \\ bkk@uctm.edu,z.yaneva@abv.bg; nvgeorgieva@vmf.uni-sz.bg
}

The adsorption behavior of 2-nitrophenol (2-NP) and 2,4-dinitrophenol (2,4-DNP) on expanded perlite (EP) at equilibrium and kinetic conditions was investigated. The experimental equilibrium data were interpreted by Langmuir, Freundlich, Redlich-Peterson, Temkin and the multilayer isotherm models. Both the Temkin and the multilayer models gave the most satisfactory representation of the experimental data for 2-NP sorption on EP covering the whole concentration range, presuming high initial sorption rate, presence of adsorbent-adsorbate chemical interactions and multilayer adsorption, as the basic characteristics featuring the equilibrium behavior of the system studied. The experimental kinetic results were analyzed by the pseudo-first, pseudo-second order models, Bangham's model, intra-particle diffusion model, and Elovich kinetic equation. The values of the calculated rate, mass transfer parameters and correlation coefficients proved that chemisorptions/intraparticle diffusion could be outlined as the basic rate controlling mechanisms during 2-NP/2,4-DNP sorption on expanded perlite. Uptake of nitrophenols increased in the order 2-NP $<2,4-\mathrm{DNP}$.

Keywords: adsorption; nitrophenols; expanded perlite; equilibrium; kinetics modelling

\section{ИСПИТУВАЊЕ НА МЕХАНИЗМОТ НА СОРПЦИЈАТА НА НИТРОФЕНОЛИ ВРЗ ЕКСПАНДИРАН ПЕРЛИТ-РАМНОТЕЖНИ И КИНЕТИЧКИ МОДЕЛИРАЊА}

Испитувано е атсорпционото однесување на 2-нитрофенол (2-NP) и 2,4-динитрофенол (2,4-DNP) на експандиран перлит (ЕР). Експерименатално добиените податоци се објаснети со Лангмуирови, Фројндлихови, Редлих-Петерсонови, Темкинови изотерми, како и со повеќеслоен изотермен модел. Темкиновиот модел и повеќеслојниот изотермен модел даваат многу задоволително објаснување на експерименталните податоци за сорпцијата на 2-NP на EP во целата област на концентрации при претпоставка за висока почетна брзина на сорпцијата, присуство на хемиската интеракција атсорбентатсорбат, како и на мултислојна атсорпција, кои се основните особини на рамнотежното однесување на испитуваниот систем. Експерименталните резултати се анализирани со моделите на кинетика од псевдо-прв, псевдо-втор ред, Банхамовиот модел, интрачестичниот дифузионен модел, како и со Еловичевата кинетичка равенка. Вредностите на пресметаните брзини, параметрите на пренос на маса и корелационите коефициенти покажуваат дека хемисорпцијата, односно интрачестичната дифузија може да се смета за главен контролен механизам на брзината на сорпцијата во системот 2-NP/2,4-DNP на експандиран перлит. Внесувањето на нитрофеноли се зголемува според редот 2-NP < 2,4-DNP.

Клучни зборови: атсорпција; нитрофеноли; експандиран перлит; рамнотежа; кинетичко моделирање 


\section{INTRODUCTION}

Nitrophenols are known to be moderately to highly toxic and recalcitrant environmental pollutants, released in the aquatic compartment from a number of sources: pesticides application; effluents from mine processing facilities, foundries, metal finishing plants, refineries, dye manufacturing plants, explosives and insect control substances production, etc. [1]. They create an oxygen demand in receiving water bodies. The Environmental Protection Agency (EPA) recommended drinking water limit of $10 \mu \mathrm{g} \mathrm{dm}^{-3}$ for $2,4-\mathrm{DNP}$. It is regulated as a priority pollutant by the Clean Water Act [2]. 2,4-DNP interferes with bacterial respiration, so unlike many hard-to-degrade organics, it is inhibitory to bacteria in high concentrations [1, 3, 4]

Perlite is a representative of the group of inorganic porous aluminosilicates. It is a siliceous ryholitic volcanic glassy rock with an amorphous structure, formed through the rapid cooling and crystallization of lava $[5,6]$. The presence of $4-6 \%$ chemically bonded water in its structure is a distinguishing feature which imparts its property to expand from 5 to 20 times its original volume when heated rapidly at $900-1150{ }^{\circ} \mathrm{C}$. At that temperature the raw perlite beads pass into pyroplastic state. Hence, the chemically combined water vaporizes, causing the formation of numerous open and latent pores that account for the light weight, low bulk density and other exceptional physical properties of expanded perlite: excellent thermal and acoustical insulator, fire resistance, etc. While the crude rock may range from transparent light gray to glossy black, the color of expanded perlite ranges from snowy white to grayish white. Since perlite is a form of natural glass, it is classified as chemically inert and has a $\mathrm{pH}$ value of approximately 7 . Perlite is very cheap and easily available natural material. Basically EP is used for construction, horticultural and industrial applications $[7,8]$
During the last years literature reports a number of investigations subjected to the applicability of natural minerals: perlites [8,9], bentonite, montmorillonite [10-12], zeolites [13-15]; by-products and waste materials from industry and agriculture [1, 16-18] for substituted phenols adsorption from liquid phase. Koumanova and Peeva-Antova proved the efficiency of perlite for 4-chlorophenol removal from aqueous medium [8]. Satisfactory results were obtained during the single-component sorption of various dyes - Methyl Violet, Basic Blue 41 and Methylene Blue on expanded, unexpanded and activated perlite [19-21]. A1kan and Dogan investigated the effect of $\mathrm{pH}$ and temperature on the adsorption behavior of $\mathrm{H}_{2} \mathrm{SO}_{4}$ activated perlite towards $\mathrm{Cu}$ (II) [22]. Other scientific teams proved the applicability of $\mathrm{EP}$ as an alternative adsorbent for $\mathrm{Ag}, \mathrm{Cu}$, $\mathrm{Hg}, \mathrm{Pb}, \mathrm{Cd}, \mathrm{Cr}$ removal from aqueous solutions $[7,23,24]$.

The aim of this study was to evaluate the adsorption capacity of expanded perlite as an alternative adsorbent for mono- and dinitrophenol adsorption from aqueous phase and to establish the mechanism of the proposed process by comparative analyses of the applicability of equilibrium (Langmuir, Freundlich, RedlichPeterson, Temkin and multilayer isotherm models) and kinetics/mass transfer (pseudofirst order, pseudo-second order, Elovich kinetic models, Bangham's equation and the intraparticle diffusion model) models. The effect of contact time, sorbent mass and sorbate nature on the kinetic behavoiur of the systems studied was investigated.

\section{EXPERIMENTAL}

\subsection{Adsorbates}

2-Nitrophenol (2-NP) and 2,4-dinitrophenol (2,4-DNP) (Merck, $99 \%$ ) were used as adsorbates in the recent investigations, without further purification. The physicochemical and molecular properties of both nitrophenols were presented elsewhere [7]. 


\subsection{Adsorbent}

The expanded perlite used in the recent study as an adsorbent for 2-NP/2,4-DNP adsorption was taken from deposits in the southern part of Bulgaria. The material had not been subjected to any treatment, i.e. it was applied in its natural form. The chemical composition and the physicochemical characteristics are presented in Table 1. Its specific surface area was determined on the basis of the Brunauer, Emmet and Teller (BET) method using a Sorptomatic 1900 (Fisons Instruments).

Table 1

\section{Chemical content and physicochemical characteristics of expanded perlite}

\begin{tabular}{ll}
\hline \hline $\mathrm{SiO}_{2}$ & $70-80 \%$ \\
$\mathrm{Al}_{2} \mathrm{O}_{3}$ & $10-15 \%$ \\
$\mathrm{Fe}_{2} \mathrm{O}_{3}$ & $<1.5 \%$ \\
$\mathrm{CaO}$ & $<1.5 \%$ \\
$\mathrm{MgO}$ & $<1 \%$ \\
$\mathrm{~K}_{2} \mathrm{O}, \mathrm{Na}_{2} \mathrm{O}$ & $<10 \%$ \\
$\mathrm{TiO}_{2}$ & - \\
$\mathrm{C} . \mathrm{L}$. & $<5 \%$ \\
\hline Specific surface area, $\mathrm{m}^{2} \mathrm{~g}^{-1}$ & 5.83 \\
Specific pore volume at $p / p^{\circ} 0,99, \mathrm{~cm}^{3} \mathrm{~g}^{-1}$ & 0.0216 \\
Monolayer volume, $\mathrm{cm}^{3} \mathrm{~g}^{-1}$ & 1.3399 \\
Mean particle size, $\mathrm{dp}^{-1} \mu \mathrm{m}$ & 37 \\
Mesopores $(\mathrm{R} 15-2,000 \AA)$ & $98.6 \%$ \\
Micropores $(\mathrm{R}<15 \AA)$ & $1.4 \%$ \\
\hline \hline
\end{tabular}

\subsection{Equilibrium studies}

The equilibrium experiments were accomplished using model solutions of 2-NP and in distilled water. The investigations for the mononitrophenol were carried out at temperature $19 \pm 2{ }^{\circ} \mathrm{C}$ and $\mathrm{pH} 6.1 \pm 0.2$. Solutions were in the concentration range $5-30 \mathrm{mg} \mathrm{dm}^{-3}$. Known amounts of perlite, $0.3 \mathrm{~g}$, were added to 100 $\mathrm{cm}^{3}$ of the model solutions in screw cap jars. The jars were shaken on a platform shaker. The solute from each jar was then filtered. The residual 2-NP concentrations in the liquid phase $\left(C_{e}\right)$ were determined spectrophotometrically. The corresponding values of 2-NP solid phase concentrations $\left(q_{e}\right)$ were calculated by the mass balance equation Eq. (1):

$$
\left(c_{o}-c_{e}\right) \cdot V=\left(q_{e}-q_{o}\right) \cdot w,
$$

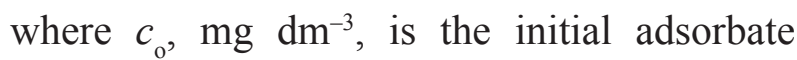
concentration in the liquid phase, $q_{\mathrm{o}}=0$ and $w$, $\mathrm{g}$, is the adsorbent mass.

\subsection{Kinetic studies}

The kinetic experiments were conducted in a standardized batch adsorber with a twobladed impeller with a Heidolph RZR 2100 motor [8]. The kinetic experiments were carried out at initial 2-NP/2,4-DNP concentration $c_{\mathrm{o}} 5 \mathrm{mg} \mathrm{dm}^{-3}$, and masses of adsorbent $w 1,6$, $10 \mathrm{~g}$ for 2-NP sorption and $w 3,4,5 \mathrm{~g}$ for 2,4DNP sorption at agitation rate $n 300 \mathrm{rpm}$.

SPECORD UV-VIS, Carl Zeiss Jena, spectrophotometer was used for concentration determinations at the corresponding wavelengths: $\lambda_{\max } 272 \mathrm{~nm}$ for $2-\mathrm{NP} ; \lambda_{\max } 254 \mathrm{~nm}$ for $2,4-\mathrm{DNP}$. The working temperature was $19 \pm 2$ ${ }^{\circ} \mathrm{C}$ and $\mathrm{pH} 6.1 \pm 0.2$. The $\mathrm{pH}$ was measured using a LHP 403T TACUSSEL pH-meter. Blanks containing no adsorbate and replicates of each adsorption point were used for each series of experiments.

\subsection{Equilibrium modelling}

\subsubsection{Langmuir model}

The Langmuir isotherm model [25], based on monolayer coverage of adsorbent surfaces by the adsorbate at specific homogeneous sites within the adsorbent, is represented as:

$$
q_{e}=\frac{K_{L} c_{e}}{1+a_{L} c_{e}},
$$


where $q_{\mathrm{e}}, \mathrm{mg} \mathrm{g}^{-1}$, is the equilibrium sorbate concentration in the solid phase; $c, \mathrm{mg} \mathrm{dm}^{-3}$, is the equilibrium sorbate concentration in the liquid phase; $a_{\mathrm{L}}, \mathrm{dm}^{3} \mathrm{mg}^{-1}$, and $K_{L}, \mathrm{dm}^{3} \mathrm{~g}^{-1}$, are the Langmuir isotherm constants, which are evaluated through linearization of Eq. (2):

$$
\frac{c_{e}}{q_{e}}=\frac{1}{K_{L}}+\frac{a_{L}}{K_{L}} c_{e}
$$

\subsubsection{Freundlich model}

The Freundlich model [26], based on multilayer adsorption on heterogeneous surfaces with a non-uniform distribution of adsorption heat, is represented as:

$$
q_{e}=K_{F} \cdot c_{e}^{n_{F}},
$$

where $K_{\mathrm{F}}, \mathrm{dm}^{3} \mathrm{~g}^{-1}$, and $n_{\mathrm{F}}-$ the heterogeneity factor, are the Freundlich constants. Their values were determined from the linear form of the Freundlich equation, given by:

$$
\log q_{e}=\log K_{F}+n_{F} \cdot \log c_{e} .
$$

\subsubsection{Redlich-Peterson model}

The three parameter Redlich-Peterson equation [27] is represented as:

$$
q_{e}=\frac{K_{R} \cdot c_{e}}{1+a_{R} c_{e}{ }^{b}},
$$

where $a_{\mathrm{R}}, \mathrm{dm}^{3} \mathrm{mg}^{-1}, K_{\mathrm{R}}, \mathrm{dm}^{3} \mathrm{~g}^{-1}$, and $b(0<b<$ 1) are the isotherm constants. For $b=1$ Eq. (6) reduces to the Langmuir equation and for $b=$ 0 - to Henry's equation. The values of the three parameters were determined by the linearized form:

$$
\ln \left(K_{R} \frac{c_{e}}{q_{e}}-1\right)=b \ln \left(c_{e}\right)+\ln \left(a_{R}\right) .
$$

\subsubsection{Temkin model}

The Temkin isotherm model [28] has been developed on the concept of chemisorption and assumes that the heat of adsorption of the sorbate molecules decreases linearly with adsorbent layer coverage due to adsorbate-adsorbent interactions. The equation and its linearized form are represented as follows:

$$
\begin{gathered}
q_{e}=\frac{R T}{b_{T}} \ln \left(K_{T} c_{e}\right), \\
q_{e}=B_{1} \operatorname{In} K_{\mathrm{T}}+\mathrm{B}_{1} \operatorname{In} \mathrm{C}_{\mathrm{e}},
\end{gathered}
$$

where $B_{1}=R T / b_{T} ; b_{T}$, mol kJ $\mathrm{J}^{-1}$, is the Temkin isotherm constant; $K_{T}, \mathrm{dm}^{3} \mathrm{mg}^{-1}$, is the equilibrium binding constant; $T, K,-$ the temperature and $R\left(8.314 \times 10^{-3} \mathrm{~kJ} \mathrm{~mol}^{-1} \mathrm{~K}^{-1}\right)$ - the universal gas constant. The isotherm parameters, $b_{T}$ and $K_{T}$, can be calculated from the slope and intercept of the linear plot of $q_{e}$ vs $\ln c_{e}$ of Eq. (9).

\subsubsection{Multilayer isotherm model}

The multilayer adsorption isotherm model described by Wang et al. [29] is expressed by the following equation:

$$
q_{e}=\frac{Q_{m} K_{1} c_{e}}{\left(1-K_{2} c_{e}\right)\left[1+\left(K_{1}-K_{2}\right) c_{e}\right]},
$$

where $Q_{\mathrm{m}}, \mathrm{mg} \mathrm{g}^{-1}$, is the maximum monolayer adsorption capacity, $K_{1}$ - the equilibrium constant for the first layer adsorption, and $K_{2}$ - the equilibrium constant for multilayer adsorption. The second order polynomial form of Eq. (10) is obtained by regrouping of the terms: 


$$
\frac{c_{e}}{q_{e}}=\frac{c_{e}^{2}\left(K_{2}^{2}-K_{1} K_{2}\right)+c_{e}\left(K_{1}-2 K_{2}\right)+1}{Q_{m} K_{1}}
$$

The values of $Q_{\mathrm{m}}, K_{1}$ and $K_{2}$ are obtained by plotting $c_{\mathrm{e}} / q_{\mathrm{e}} \mathrm{vs} c_{e}$ and adjusting to a secondorder polynomial equation.

\subsection{Kinetics modelling}

In order to investigate the mechanism of 2-NP and 2,4-DNP sorption on expanded perlite, the applicability of the pseudo-first order, pseudo-second order, Elovich kinetic models, Bangham's equation and the intraparticle diffusion model were examined.

\subsubsection{Pseudo-first order kinetic model}

The pseudo-first order equation represented by Lagergren [30] is expressed as:

$$
\frac{d q_{t}}{d t}=k_{1}\left(q_{e}-q_{t}\right)
$$

where $q_{e}$ and $q_{t}, \mathrm{mg} \mathrm{g}^{-1}$, are the sorption capacity at equilibrium and at time $t$, respectively, and $k_{1}, \mathrm{~min}^{-1}$, is the rate constant of pseudo-first order sorption. After integration and applying boundary conditions $t=0$ to $t=t$ and $q_{t}=0$ to $q_{t}=q_{t}$, the integrated form of Eq. (12) becomes:

$$
\log \left(q_{e}-q_{t}\right)=\log q_{e}-\frac{k_{1}}{2.303} t
$$

To obtain the rate constants, the straight line plots of $\log \left(q_{e}-q_{t}\right)$ against $t$ for the nitrophenol at different conditions were tested.

\subsubsection{Pseudo-second order kinetic model}

The pseudo-second order chemisorption kinetic rate equation is expressed as [31]:

$$
\frac{d q_{t}}{d t}=k_{2}\left(q_{e}-q_{t}\right)^{2}
$$

where $k_{2}, \mathrm{~g} \mathrm{mg}^{-1} \mathrm{~min}^{-1}$, is the rate constant of pseudo-second order sorption. For the boundary conditions $t=0$ to $t=t$ and $q_{t}=0$ to $q_{t}=q_{t}$, the integrated form of Eq. (14) becomes:

$$
\frac{1}{q_{e}-q_{t}}=\frac{1}{q_{e}}+k_{2} t
$$

It can be rearranged in a linear form:

$$
\frac{1}{q_{t}}=\frac{1}{k_{2} q_{e}^{2}}+\frac{1}{q_{e}} t
$$

where $h$ can be regarded as the initial sorption rate as $q_{t} / t \rightarrow 0$, hence:

$$
h=k_{2} \cdot q_{e}^{2} .
$$

\subsubsection{Elovich kinetic model}

Elovich kinetic model [32] is based on chemisorption phenomena. It is expressed as:

$$
\frac{d q}{d t}=\alpha \exp (-\omega \cdot q)
$$

In order to simplify Elovich equation, Chine and Clayton [33] assumed that $\omega \cdot t>>1$, and when the boundary conditions $q=$ 0 at $t=0$ and $q=q$ at $t=t$, are applied the equation becomes

$$
q_{t}=\frac{1}{\omega} \ln (\alpha \cdot \omega)+\frac{1}{\omega} \ln t
$$

where $q_{t} \mathrm{mg} \mathrm{g}^{-1}$, is the adsorbate concentration in the solid phase at time $t$, min; $\alpha, \mathrm{mg} \mathrm{g}^{-1} \mathrm{~min}^{-1}$, is the initial adsorption rate, and $\omega, \mathrm{g} \mathrm{mg}^{-1}$, is related to the extent of surface coverage and the activation energy for chemisorption. Eq. (19) can be rearranged as: 


$$
q t=\mathrm{A}+\mathrm{B} \operatorname{In} t
$$

where $A=1 / \omega \ln (\alpha \cdot \omega)$ and $B=1 / \omega$. The values of $A$ and $B$ can be calculated by the intercept and slope of the linear plot of Eq. (20).

\subsubsection{Bangham's equation}

Bangham's model [34] tests if pore diffusion is the only rate controlling step of an adsorption process. The model can be represented by the following equation

$$
\log \left[\log \left(\frac{c_{o}}{c_{o}-q_{t} m}\right)\right]=\log \left(\frac{k_{o} m}{2.303 V}\right)+\sigma \log t,
$$

where $c_{\mathrm{o}}, \mathrm{mg} \mathrm{dm}^{-3}$, is the initial sorbate concentration in the liquid phase; $q_{t}, \mathrm{mg} \mathrm{g}^{-1}$ - sorbate concentration in the solid phase at time $t$, min; $m, \mathrm{~g} \mathrm{dm}^{-3}$ - adsorbent concentration; $V$, $\mathrm{dm}^{3}-$ solution volume; $k_{\mathrm{o}}, \mathrm{dm}^{-1}$, and $\sigma(\sigma<$ 1) - Bangham's equation parameters.

\subsubsection{Intraparticle diffusion model}

The rate parameter of intraparticle diffusion [35] can be defined as:

$$
q_{t}=k_{i} t^{0.5}+I
$$

where $k_{\mathrm{i}}, \mathrm{mg} \mathrm{g}^{-1} \mathrm{~min}^{-0.5}$, is the intraparticle diffusion rate constant.

The $k_{\mathrm{i}}$ values were calculated from the slopes of the straight line regions of the respective plots $q_{\mathrm{t}}$ against $t^{0.5}$ and $I$ is the intercept which gives an idea about the thickness of the boundary layer on the adsorbent surface.

\section{RESULTS AND DISCUSSION}

\subsection{Adsorption equilibrium}

The experimental equilibrium data of 2-NP adsorption on EP were described by the Langmuir, Freundlich, Redlich-Peterson, Temkin and the multilayer isotherm models (Fig. 1). The calculated model parameters, regression coefficients $\left(R^{2}\right)$, sum of square error (SSE) and root mean of square error (RMSE) values are presented in Table 2.

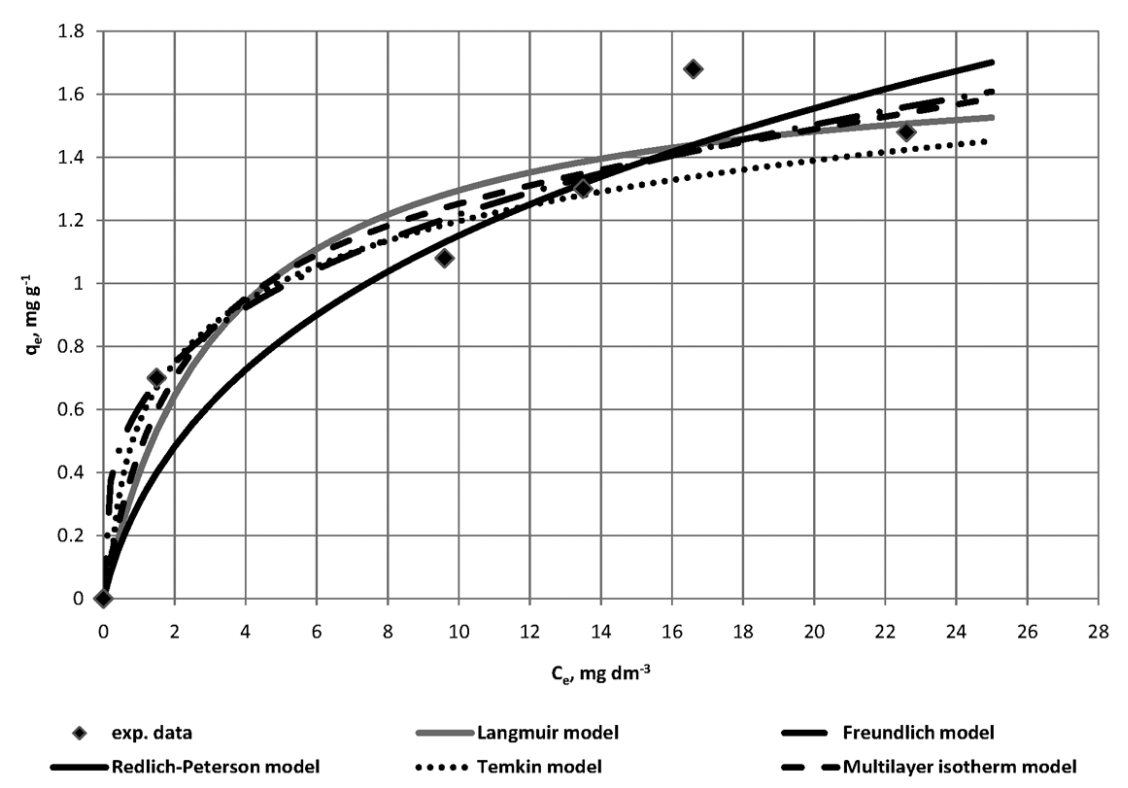

Fig. 1. Experimental isotherm, Langmuir model, Freundlich model, Redlich-Peterson, Temkin and multilayer isotherm model of 2-NP adsorption on EP 
The experimental isotherm (Figure 1) was concave and favourable, characterized with an initial steep section. The maximum attained adsorption capacity was $q_{\mathrm{e}} 1.68 \mathrm{mg} \mathrm{g}^{-1}$. The values of $R^{2}$ for the Temkin and the multilayer isotherm models (Figure 2) were commensurable and the highest (Table 2).

Table 2

Values of the Langmuir, Freundlich, Redlich-

Peterson, Temkin and multilayer isotherm model coefficients, SSE (Sum of Square Error) and RMSE (Root Mean Square Error) for the system 2-NP-expanded perlite

\begin{tabular}{|c|c|c|c|c|}
\hline Model & Coefficients & $R^{2}$ & SSE & RMSE \\
\hline Langmuir & $\begin{array}{l}K_{L} 0.5133 \\
a_{L} 0.2964\end{array}$ & 0.9365 & 0.1345 & 0.1640 \\
\hline Freundlich & $\begin{array}{l}K_{F} 0.6067 \\
n_{F} 0.3029\end{array}$ & 0.9061 & 0.0902 & 0.1344 \\
\hline $\begin{array}{l}\text { Redlich- } \\
\text { Peterson }\end{array}$ & $\begin{array}{c}K_{R} 0.5133 \\
a_{R} 0.6963 \\
b 0.6960\end{array}$ & 0.7815 & 0.1743 & 0.1867 \\
\hline $\begin{array}{l}\text { Multilayer } \\
\text { isotherm }\end{array}$ & $\begin{array}{l}K_{1} 0.4990 \\
K_{2} 0.0075 \\
Q_{\mathrm{m}} 1.3735 \\
\end{array}$ & 0.9407 & 0.1100 & 0.1484 \\
\hline Temkin & $\begin{array}{l}b_{T} 8.7721 \\
K_{T} 7.4532 \\
B_{1} 0.2777\end{array}$ & 0.9538 & 0.1326 & 0.1629 \\
\hline
\end{tabular}

However, according to the mode of the experimental and model equilibrium curves, obviously, the Langmuir model displayed good correlation with the experimental data only for the low and middle concentration range. Similar tendency was observed when the Freundlich and Temkin models were applied. The model isotherm predicted by the Redlich-Peterson model, however, was more suitable for the middle and higher concentration ranges. The experimental points outlined a distinct steep vertical section in the low concentration region, where a sharp leap of nitrophenol solid phase concentration from 0 to $0.7 \mathrm{mg} \mathrm{g}^{-1}$ was distinguished (Figure 1).

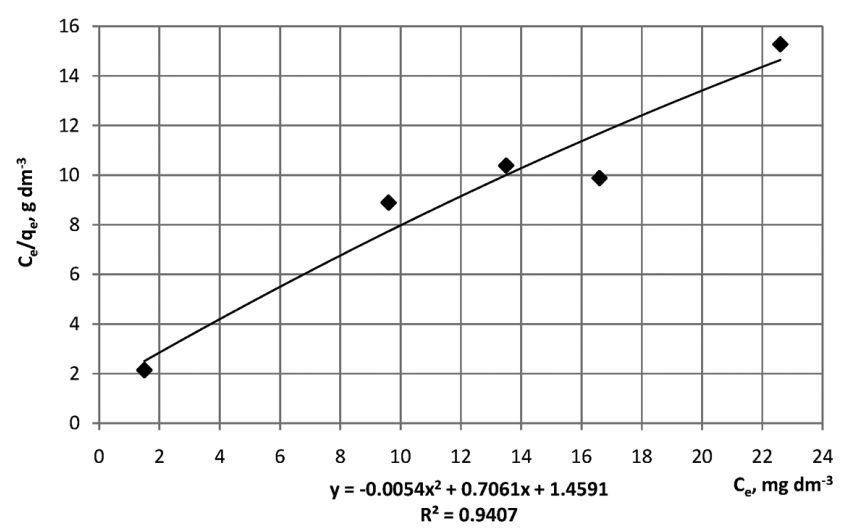

Fig. 2. Second order polynomial form of the multilayer isotherm model for 2-NP adsorption on EP

Consequently, higher extent of adsorption during the initial stages of the process could be expected. The above stated conclusion was consistent with the significantly higher value of the equilibrium constant for the first layer adsorption $\left(K_{1} 0.4990\right)$ than that for the multilayer sorption $\left(K_{2} 0.0075\right)$, calculated by the multilayer model (Table 2). Hence, a greater number of 2-NP molecules were sorbed on the first sorbent layer; however the process proceeded to the inner layers of the solid particles, although at a lower rate and smaller magnitude. Besides, the proven applicability of the Temkin model for the lower concentration region signified uniform distribution of binding energy and a linear decrease of the heat of adsorption of the molecules in the first layers with coverage of the adsorbate on the surface of the adsorbent particles $[36,37]$. Moreover, the concept of chemisorption during these initial process stages was also consistent. The monolayer capacity displayed as $K_{\mathrm{L}} / a_{\mathrm{L}}$ according to the Langmuir model was $1.73 \mathrm{mg} \mathrm{g}^{-1}$, while that calculated by the linearized form of the multilayer isotherm model was $Q_{\mathrm{m}} 1.37 \mathrm{mg} \mathrm{g}^{-1}$. The observed difference in the values of the monolayer capacity was logical, as the Langmuir model assumed monolayer coverage of adsorbent surfaces by the adsorbate at specific homogeneous sites within the adsorbent, while the multilayer model was based on the conception of multilayer adsorption. 
Based on these observations, it could be concluded that both the Temkin and the multilayer models gave the most satisfactory representation of the experimental data for 2-NP adsorption on EP covering the whole concentration range, presuming high initial sorption rate, presence of adsorbent-adsorbate chemical interactions and multilayer adsorption, as the basic characteristics featuring the equilibrium behavior of the system studied.

\subsection{Adsorption kinetics}

The study of adsorption kinetics in wastewater treatment is significant as it provides valuable information for the magnitude and mechanism of the proposed process. Kinetics describes the solute uptake rate, which in turn controls the residence time of sorbate uptake at the solid-liquid interface.

The effect of contact time, adsorbent mass and adsorbate nature on the kinetics of 2-NP and 2,4-DNP on the natural material EP was examined. The mechanism of the process studied was analyzed on the basis of a comparative estimation of the applicability of the pseudo-first order, pseudo-second order, Elovich kinetic models; Bangham's equation and the intraparticle diffusion model.

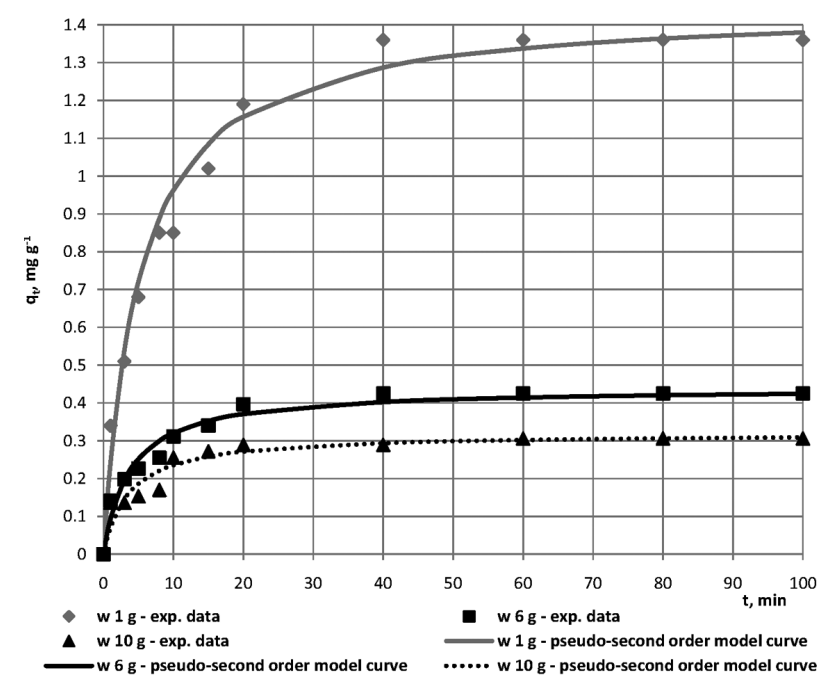

Fig. 3. Experimental and pseudo-second order model kinetic curves for 2-NP adsorption on EP
The experimental kinetic curves for 2-NP and 2,4-DNP sorption on EP, presented as a plot of $q_{t}$ vs $t$, are displayed in Figures 3 and 4, respectively. The equilibrium adsorption capacity for both systems decreased (from 1.36 to 0.31 $\mathrm{mg} \mathrm{g}^{-1}$ for 2-NP-EP; from 1.58 to $1.09 \mathrm{mg} \mathrm{g}^{-1}$ for 2,4-DNP-EP) with the adsorbent mass increase. The adsorbent loading increased when its mass was decreased, as a unit sorbent mass contacted a greater number of sorbate molecules. The sorption rate in the initial stages of the process was the highest. The system 2,4-DNP - EP reached equilibrium, indicated by the horizontal section of the kinetic curves, approximately $30 \mathrm{~min}$ after the beginning of the process, while the system 2-NP EP after 50-60 min.

The values of the calculated models parameters and regression coefficients are presented in Tables 3, 4. Obviously, the pseudosecond order model characterized with the highest values of the correlation coefficients $\left(R_{2}^{2}>0.9973\right)$ (Figure 5) for both systems, signifying the dominating role of chemisorption during mono- and dinitrophenols sorption on the mineral. The comparative analyses of the mode of the experimental and pseudo-second order model kinetic curves (Figures 3 and 4), as well as the much more reasonable values of the calculated equilibrium capacities $\left(q_{\mathrm{e} 2}\right)$ com-

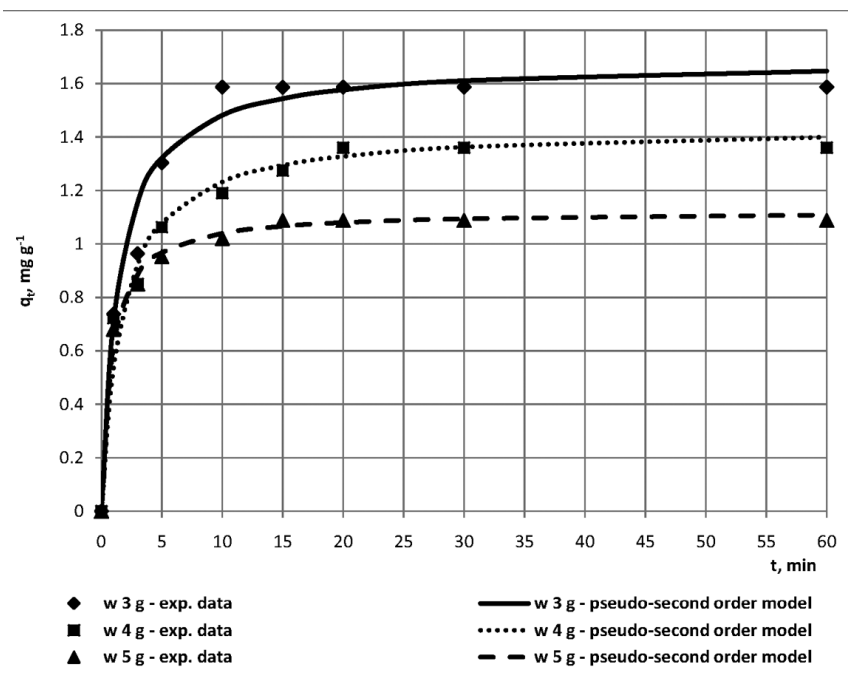

Fig. 4. Experimental and pseudo-second order model kinetic curves for 2,4-DNP adsorption on EP 
pared to $q_{\mathrm{e} 1}$, obtained by the pseudo-first order model also evidenced the latter conclusion. Although the values of the regression coefficients of the Elovich kinetic model $\left(R_{\mathrm{e}}^{2}\right)$ were lower than $R_{2}^{2}$, a direct correlation between perlite mass, $w$, and the values of kinetic parameter $\omega$ for both systems was observed, i.e. an outlined tendency of increasing the extent of surface coverage and the activation energy for chemisorption was established.

The commensurable and relatively high values of $R_{\mathrm{B}}{ }^{2}$ and $R_{\mathrm{i}}^{2}$ for both studied systems, calculated by the Bangham's and the intrapar- ticle diffusion models proved the significant role of intraparticle diffusion as one of the probable rate controlling mechanisms during nitrophenols adsorption on expanded perlite. The inversely proportional relationship between the values of the intraparticle rate parameters $k_{\mathrm{o}}$ and $k_{\mathrm{i}}$ (Tables $3,4)$, and sorbent mass indicated reduction of the intraparticle diffusion rate. Consequently, the larger solid phase amount defined larger external mass transfer surface area available for adsorption, followed by a sharp decrease of sorbate concentration in the liquid phase, and respectively a decrease in the process driving force.

$\mathrm{T}$ a b 1 e 3

Values of the kinetic and diffusion parameters characterizing 2-NP sorption on expanded perlite

\begin{tabular}{|c|c|c|c|c|c|}
\hline $\begin{array}{l}\text { Pseudo-first order } \\
\text { model }\end{array}$ & $k_{1}, \min ^{-1}$ & $q_{e 1}, \mathrm{mg} \mathrm{g}^{-1}$ & $q_{\text {exp }}, \mathrm{mg} \mathrm{g}^{-1}$ & & $R_{1}^{2}$ \\
\hline $1 \mathrm{~g}$ & 0.0928 & 1.18 & 1.36 & & 0.9741 \\
\hline $6 \mathrm{~g}$ & 0.1172 & 0.37 & 0.42 & & 0.9552 \\
\hline $10 \mathrm{~g}$ & 0.1366 & 0.27 & 0.31 & & 0.9420 \\
\hline $\begin{array}{l}\text { Pseudo-second order } \\
\text { model }\end{array}$ & $k_{2}, \mathrm{~g} \mathrm{mg}^{-1} \mathrm{~min}^{-1}$ & $q_{e 2}, \mathrm{mg} \mathrm{g}^{-1}$ & $q_{\mathrm{exp}}, \mathrm{mg} \mathrm{g}^{-1}$ & $h, \mathrm{mg} \mathrm{g}^{-1} \min ^{-1}$ & $R_{2}^{2}$ \\
\hline $1 \mathrm{~g}$ & 0.1361 & 1.45 & 1.36 & 0.2862 & 0.9983 \\
\hline $6 \mathrm{~g}$ & 0.6066 & 0.44 & 0.42 & 0.1174 & 0.9986 \\
\hline $10 \mathrm{~g}$ & 0.8675 & 0.32 & 0.31 & 0.0888 & 0.9977 \\
\hline Bangham's equation & $k_{0}, \mathrm{dm}^{3} \mathrm{~g}^{-1}$ & $\sigma$ & & & $R_{\mathrm{B}}^{2}$ \\
\hline $1 \mathrm{~g}$ & 0.1204 & 0.4107 & & & 0.9872 \\
\hline $6 \mathrm{~g}$ & 0.0497 & 0.3537 & & & 0.9771 \\
\hline $10 \mathrm{~g}$ & 0.0435 & 0.2865 & & & 0.8253 \\
\hline Elovich model & $A$ & $B$ & $\omega, \mathrm{g} \mathrm{mg}^{-1}$ & $\alpha, \mathrm{mg} \mathrm{g}^{-1} \min ^{-1}$ & $R_{\mathrm{E}}^{2}$ \\
\hline $1 \mathrm{~g}$ & 0.2540 & 0.2893 & 3.4566 & 0.6961 & 0.9699 \\
\hline $6 \mathrm{~g}$ & 0.1158 & 0.0831 & 12.0337 & 0.3348 & 0.9494 \\
\hline $10 \mathrm{~g}$ & 0.1053 & 0.0514 & 19.4553 & 0.3987 & 0.8241 \\
\hline $\begin{array}{c}\text { Intraparticle diffusion } \\
\text { model }\end{array}$ & $k_{\mathrm{i}}, \mathrm{mg} \mathrm{g}^{-1} \min ^{-0.5}$ & $I$ & & & $R_{\mathrm{i}}^{2}$ \\
\hline $1 \mathrm{~g}$ & 0.2403 & 0.1145 & & & 0.9887 \\
\hline $6 \mathrm{~g}$ & 0.0722 & 0.0681 & & & 0.9857 \\
\hline $10 \mathrm{~g}$ & 0.0520 & 0.0582 & & & 0.8641 \\
\hline
\end{tabular}


T a b le 4

Values of the kinetic and diffusion parameters characterizing 2,4-DNP sorption on expanded perlite

\begin{tabular}{cccccc}
\hline \hline $\begin{array}{c}\text { Pseudo-first order } \\
\text { model }\end{array}$ & $k_{1}, \mathrm{~min}^{-1}$ & $q_{e 1}, \mathrm{mg} \mathrm{g}^{-1}$ & $q_{\text {exp }}, \mathrm{mg} \mathrm{g}^{-1}$ & & $R_{1}{ }^{2}$ \\
\hline $3 \mathrm{~g}$ & 0.3160 & 1.42 & 1.58 & & 0.9560 \\
$4 \mathrm{~g}$ & 0.1658 & 0.90 & 1.36 & & 0.9385 \\
$5 \mathrm{~g}$ & 0.0419 & 0.68 & 1.09 & & 0.6093 \\
\hline $\begin{array}{c}\text { Pseudo-second order } \\
\text { model }\end{array}$ & $k_{2}, \mathrm{~g} \mathrm{mg}^{-1} \mathrm{~min}^{-1}$ & $q_{e 2}, \mathrm{mg} \mathrm{g}^{-1}$ & $q_{\text {exp }}, \mathrm{mg} \mathrm{g}^{-1}$ & $h, \mathrm{mg} \mathrm{g}^{-1} \mathrm{~min}^{-1}$ & $R_{2}{ }^{2}$ \\
\hline $3 \mathrm{~g}$ & 0.4326 & 1.68 & 1.58 & 1.2274 & 0.9973 \\
$4 \mathrm{~g}$ & 0.4148 & 1.44 & 1.36 & 0.8582 & 0.9982 \\
$5 \mathrm{~g}$ & 1.1052 & 1.12 & 1.09 & 1.3945 & 0.9996 \\
\hline Bangham's equation & $k_{0}, \mathrm{dm}^{3} \mathrm{~g}^{-1}$ & $\sigma$ & & & $R_{\mathrm{B}}{ }^{2}$ \\
\hline $3 \mathrm{~g}$ & 0.2764 & 0.4461 & & & 0.9666 \\
$4 \mathrm{~g}$ & 0.2895 & 0.3089 & & & 0.9780 \\
$5 \mathrm{~g}$ & 0.3013 & 0.2537 & & & 0.9892 \\
\hline Elovich model & $A$ & $B$ & $\omega, \mathrm{g} \mathrm{mg}^{-1}$ & $\alpha, \mathrm{mg} \mathrm{g}^{-1} \mathrm{~min}^{-1}$ & $R_{\mathrm{E}}{ }^{2}$ \\
\hline $3 \mathrm{~g}$ & 0.6772 & 0.3754 & 2.6638 & 2.2800 & 0.9476 \\
$4 \mathrm{~g}$ & 0.6853 & 0.2192 & 4.5620 & 4.9958 & 0.9738 \\
$5 \mathrm{~g}$ & 0.6872 & 0.1495 & 6.6890 & 14.8231 & 0.9923 \\
\hline Intraparticle diffusion & $k_{\mathrm{i}}, \mathrm{mg} \mathrm{g}^{-1} \mathrm{~min}^{-0.5}$ & $I$ & & & $R_{\mathrm{i}}{ }^{2}$ \\
\hline model & 0.4072 & 0.3199 & & & 0.9770 \\
\hline $3 \mathrm{~g}$ & 0.1984 & 0.5438 & & & 0.9570 \\
$4 \mathrm{~g}$ & 0.2209 & 0.4615 & & & 0.9986 \\
\hline $5 \mathrm{~g}$ & & & &
\end{tabular}

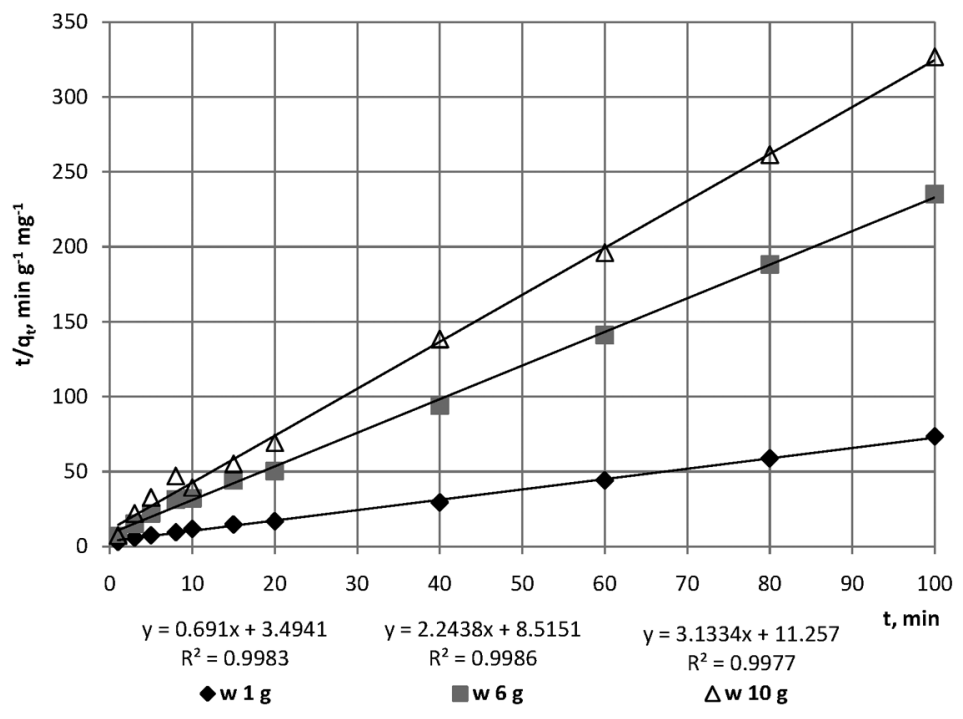

Fig. 5. Pseudo-second order kinetic model for the system 2-NP-EP 
The experimental kinetic data for 2-NP/2,4DNP sorption on perlite were modeled by Bangham's equation based on the assumption that pore diffusion was the only rate controlling step during adsorption. The values of the correlation coefficients (RB2) (Tables 3, 4) calculated by the double logarithmic plots (Figure 6) were relatively high but lower than $R_{2}^{2}$ values for both investigated systems. Thus, definitely the contribution of pore diffusion to the overall mechanism of nitrophenols adsorption could not be neglected, and it could even turn up as one of the rate limiting mechanisms during the different process stages.

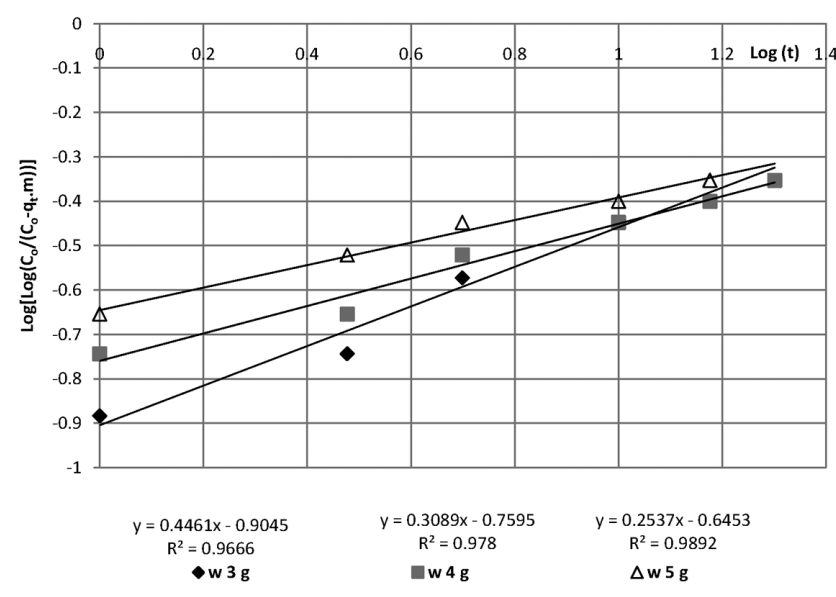

Fig. 6. Linear form of Bangham's model applied for the system 2,4-DNP - EP

The straight line plots of $t / q_{t}$ vs $t^{0.5}$, representing the intraparticle diffusion model, have also been analyzed. For a great number of sorbents, these plots are multilinear, i.e. depicting the influence of two or more rate controlling steps during adsorption, as well as intraparticle diffusion in pores with different size. The plots presented in Figures 7 and 8, for the systems 2-NP-EP and 2,4-DNP-EP, respectively, characterized with a short initial portion, related to possible external mass transfer effects, followed by two linear sections: the first attributed to diffusion in the mesopores of the sorbent and the second - to micropore diffusion. The latter conclusion was supported by the fact that expanded perlite belongs to the group of the mesoporous sorbents (Table 1). The parameter $I$ is associated with the thickness of the boundary layer. Consequently the higher determined $I$ values for the system 2,4-DNP-EP (Table 4) were indicative for the more significant influence of external mass transfer during dinitrophenol adsorption on the natural mineral when compared to the mononitrophenol sorption (Table 3).

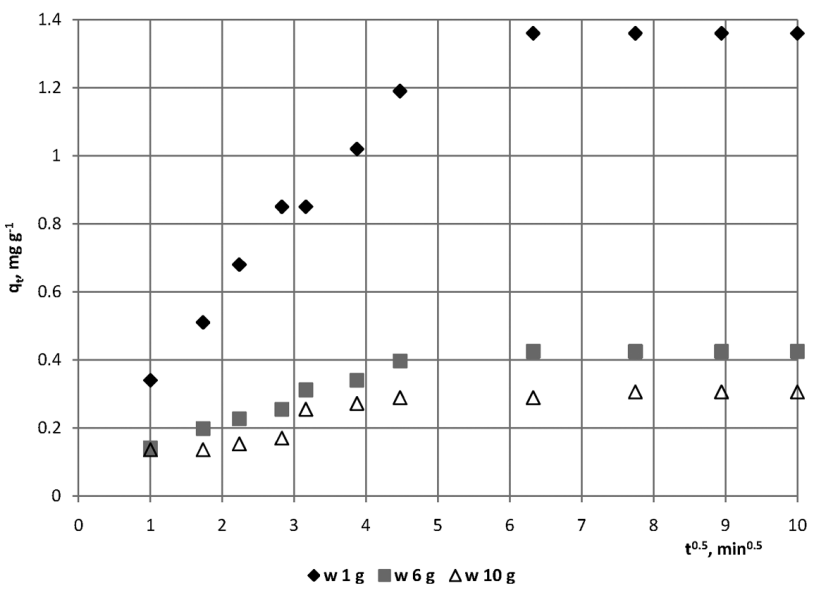

Fig. 7. Intraparticle diffusion model applied for the system 2-NP-EP

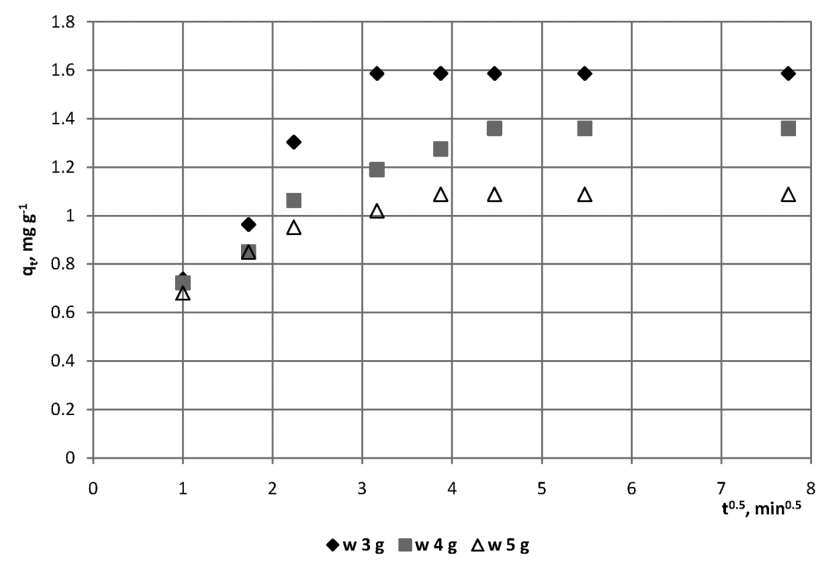

Fig. 8. Intraparticle diffusion model applied for the system 2,4-DNP-EP

The comparative analyses of the applicability of the tested kinetic models proved undoubtedly that both chemisorption and intraparticle diffusion could be outlined as the basic rate controlling mechanism during nitrophenols sorption on expanded perlite.

According to a number of scientific investigations the adsorption activity of EP was due basically to the presence of surface hydrox$\mathrm{yl}$ groups in its structure. The surface $\mathrm{Si}$ atoms 
sustained their tetrahedral coordination with O-atoms. The latter spatial position was stabilized at room temperature through the binding of monovalent $\mathrm{OH}$-groups and the formation of silanol groups. It is theoretically possible that a single Si-atom was bonded to two or three $\mathrm{OH}-$ groups, hence silanediol or silanetriol groups were formed. Besides, the $\mathrm{OH}$-groups on the surface are bonded with Al-atoms [38].

Although the recent investigations demonstrated similar trends and correlation relationships between the analyzed kinetic and mass transfer parameters, it should be emphasized that they represent two different classes of substituted phenols. Due to differences in their molecular structures they exhibit specific physical and chemical properties and were re-

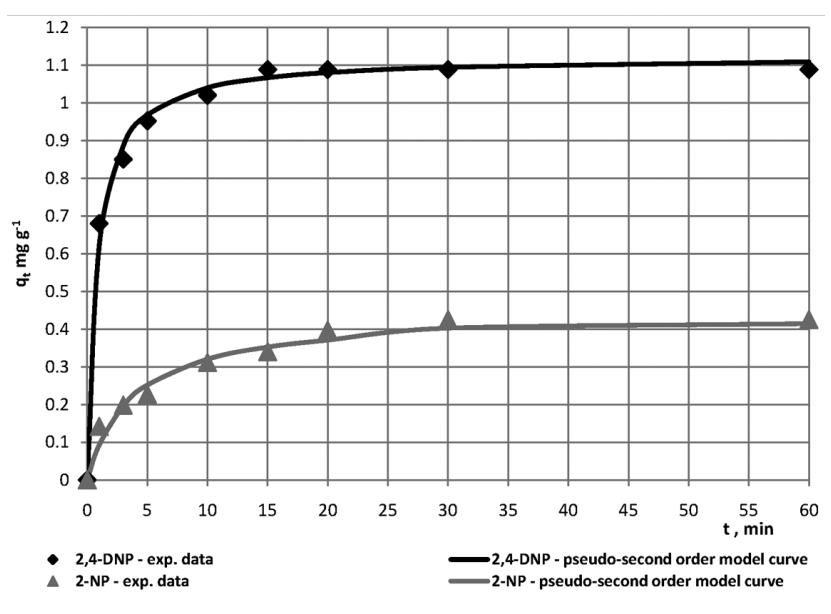

Fig. 9. Comparison of the experimental and pseudosecond order model kinetic curves of 2-NP and 2,4-DNP sorption on EP

sponsible for some deviations in their sorption behavior.

The effect of adsorbate nature on the mechanism of the sorption process was assessed by comparison of the kinetic curves for both nitrophenols (Figure 9) obtained at equal initial sorbate concentrations $-c_{\mathrm{o}} 5 \mathrm{mg} \mathrm{dm}^{-3}$, perlite mass $6 \mathrm{~g}$ for the experiment with 2-NP and $5 \mathrm{~g}$ for the experiment with 2,4-DNP and equal agitation rate $n 300 \mathrm{rpm}$. The maximum adsorption capacity of EP for 2,4-DNP $\left(q_{\mathrm{e}}^{\exp }\right.$ $1.09 \mathrm{mg} \mathrm{g}^{-1}$ ) was 2.6 times higher than that for 2-NP $\left(q_{\mathrm{e}}^{\exp } 0.42 \mathrm{mg} \mathrm{g}^{-1}\right)$. Thus, during the parallel batch equilibrium experiments a greater relative part of 2,4-DNP molecules were sorbed on the surface and in the pores of the sorbent particles. Probably the second $\mathrm{NO}_{2}-$ group in the 2,4-DNP molecule in paraposition in the aromatic ring displayed affinity for electron exchange activities. While the $\mathrm{O}$-atom from the $\mathrm{NO}_{2}$-group in orthoposition for 2-NP and 2,4-DNP is capable of forming an intramolecular hydrogen bond with the $\mathrm{H}$-atom from the $\mathrm{OH}$-group. Thus, it could hardly participate in chemical reactions and is responsible for the lower solubility of 2-NP in water compared to 2,4-DNP, where the OH-group in paraposition does not form a hydrogen bond with the $\mathrm{NO}_{2}$ group. From another aspect, as stated above, expanded perlite belongs to the group of the mesoporous sorbents. Hence, considering that the effective molecular diameters of the nitrophenols studied: $0.813 \mathrm{~nm}$ for 2-NP and 0.872 $\mathrm{nm}$ for 2,4-DNP, are smaller than perlite pore sizes, the assumption of dimensional limitations seemed inconsistent. The linear regions displayed in Figure 7 for 2-NP adsorption according to the intraparticle diffusion model were considerately more explicit that those for the system 2,4-DNP - expanded perlite (Figure 8 ). One of the probable reasons could be either pore blockage by the larger dinitrophenol molecules or retention of the organic molecules on the mesopore walls resulting from chemical interactions. Analogous behavior during monoand dinitrophenols sorption on the clay mineral yellow bentonite was observed in previous our investigations [12].

\section{CONCLUSIONS}

The equilibrium adsorption behavior of 2-NP on expanded perlite from aqueous medium was investigated. The Temkin and the multilayer isotherms provided the best correlation between the experimental and theoretical results. The theoretical kinetic curves of 2-NP 
and 2,4-DNP adsorption, obtained at different sorbent masses, on EP predicted by the pseudo-second order model displayed an extremely high degree of correlation $\left(R_{2}^{2}>0.9973\right)$ with the experimental data. Consequently, the major rate limiting step might be chemical adsorption or chemisorption involving valency forces through exchange of electrons between the sorbate and the sorbent, however, the contribution of pore diffusion to the overall mechanism of nitrophenols adsorption could not be neglected. The disubstituted nitrophenol exhibited higher affinity to expanded perlite than 2-NP.

\section{REFERENCES}

[1] N. Z. Al-Mutairi, 2,4-Dinitrophenol adsorption by date seeds: Effect of physico-chemical environment and regeneration study, Desalination 250, 892-901 (2010).

[2] US Environmental Protection Agency, Water-related Environmental Fate of 129 Priority Pollutants: Volume II: Office of Water Planning and Standards, Office of Water and Waste Management, U.S. Environmental Protection Agency, Washington, D.C., (1979).

[3] L. Virginia, A. Gemini, T. Valeria, C. Daniel, P. Estela, K. Sonia, Microbial degradation and detoxification of 2,4-dinitrophenol in aerobic and anoxic processes, Int. Biodeterior. Biodegrad. 60, 226-230 (2007).

[4] S. Zonglian, G. Mengchun, J. Chunji, C. Youyuan, Y. Jianwei, Toxicity and biodegradation of 2, 4-dinitrophenol and 3-nitrophenol in anaerobic systems, Process Biochem. 40, 3017-3024 (2005).

[5] K. Swayampakula, V. M. Boddu, S. K. Nadavala, K. Abburi, Competitive adsorption of $\mathrm{Cu}(\mathrm{II}), \mathrm{Co}(\mathrm{II})$ and $\mathrm{Ni}(\mathrm{II})$ from their binary and tertiary aqueous solutions using chitosan-coated perlite beads as biosorbent, J. Haz. Mat. 170, 680-689 (2009).

[6] T. Mathialagan, T. Viraraghavan, Adsorption of cadmium from aqueous solutions by perlite, J. Haz. Mater. B94, 291-303 (2002).

[7] B. Koumanova, Z. Yaneva, Low cost adsorbents for the removal of nitrophenols from wastewaters, Management of Intentional and Accidental Water Pollution, NATO Security through Science Series, Springer, 263-275 (2006).

[8] [8] B. Koumanova, P. Peeva-Antova, Adsorption of p-chlorophenol from aqueous solutions on bentonite and perlite, J. Haz. Mat. 90, 229-234 (2002).
[9] Z. Yaneva, B. Koumanova, V. Meshko, Dynamic studies of nitrophenols adsorption on perfil in a fixed-bed column: Application of single and two resistance model, Water Sci. Technol. 62.4, 883-891 (2009).

[10] P. Ye, A. T. Lemley, Adsorption effect on the degradation of 4,6-o-dinitrocresol and $p$-nitrophenol in a montmorillonite clay slurry by AFT, Wat. Res. 43, 1303-1312 (2009).

[11] M. Majdan, M. Bujacka, E. Sabah, A. G1adysz-P1aska, S. Pikus, D. Sternik, Z. Komosa, A. Padewski, Unexpected difference in phenol sorption on PTMA- and BTMA-bentonite, J. Environ. Management 91, 195-205 (2009).

[12] Z. Yaneva, B. Koumanova, Comparative modeling of mono- and dinitrophenols sorption on yellow bentonite from aqueous solutions, J. Colloid Interface Sci. 293, 303-311 (2006).

[13] C. Muciz-Lopez, J. Duconge, R. Roque-Malherbe, Paranitrophenol liquid-phase adsorption in dealuminated Y zeolite, J. Colloid Interface Sci. 329, 11-16 (2009).

[14] T. Sismanoglu, S. Pura, Adsorption of aqueous nitrophenols on clinoptilolite, Colloids and Surfaces, A: Physicochemical and Engineering Aspects, 180 (2001) 1-6.

[15] Z. Kircheva, G. Oltean, D. Covaciu, B. Koumanova, M. Zitaru, Equilibrium study of 4-nitrophenol adsorption on natural materials from aqueous solutions, J. Univ. Chem. Technol. Met. (Sofia) 39, 343-350 (2004).

[16] B. Koumanova, P. Peeva, S. J. Allen, K. A. Gallagher, M. G. Healy, Biosorption from aqueous solutions by egg-shell membranes and Rhizopus Oryzae: Equilibrium and kinetic studies, J. Chem. Technol. Biotechnol. 77, 539-545 (2002).

[17] S. J. Allen, B. Koumanova, Z. Kircheva, S. Nenkova, Adsorption of 2-nitrophenol by Technical Hydrolysis Lignin: Kinetics, Mass Transfer and Equilibrium Studies, Ind. Eng. Chem. Res. 44, 2281-2287 (2005).

[18] F. Delval, G. Crini, J. Vebrel, Removal of organic pollutants from aqueous solutions by adsorbents prepared from an agroalimentary by-product, Bioresource Technol. 97, 2173-2181 (2006).

[19] M. Dogan, M. Alkan, Removal of methyl violet from aqueous solution by perlite, J. Colloid Interface Sci. 267, 36-41 (2003).

[20] M. Roulia, A. A. Vassiliadis, Interactions between C. I. Basic Blue 41 and aluminosilicate sorbents, $J$. Colloid Interface Sci. 291, 37-44 (2005). 
[21] M. Dogan, M. Alkan, Y. Onganer, Adsorption of Methylene Blue from aqueous solution onto perlite, Water, Air and Soil Pollution 120, 229-248 (2000).

[22] M. Alkan, M. Dogan, Adsorption of copper(II) onto perlite, J. Colloid Interface Sci. 243, 280-291 (2001).

[23] H. Ghassabzadeh, A. Mohadespour, M. TorabMostaedi, P. Zaheri, M. G. Maragheh, H. Taheri, Adsorption of $\mathrm{Ag}, \mathrm{Cu}$ and $\mathrm{Hg}$ from aqueous solutions using expanded perlite, J. Haz. Mat. 177, 950-955 (2010).

[24] S. K. R. Yadanaparthi, D. Graybill, R. von Wandruszka, Adsorbents for the removal of arsenic, cadmium, and lead from contaminated waters Review, J. Haz. Mat. 191, 1-15 (2009).

[25] I. Langmuir, The constitution and fundamental properties of solids and liquids, J. Am. Chem. Soc. 38, 2221 (1916).

[26] H. Freundlich, Über die Adsorption in Lösungen, J. Phys. Chem. 57, 385-470 (1907).

[27] O. Redlich, D. L. Peterson, A useful adsorption isotherm, J. Phys. Chem. 63, 1024-1026 (1959).

[28] M. J. Temkin, V. Pyzhev, Kinetics of ammonia synthesis on promoted iron catalysis, Acta Physicochim. USSR 12, 217-222 (1940).

[29] J. Wang, C. P. Huang, H. E. Allen, D. K. Cha, D. W. Kim, Adsorption characteristics of dye onto sludge particulates, J. Colloid Interface Sci. 208, 518-528 (1998).
[30] S. Lagergren, Zur Theorie der sogenannten adsorption gelöster Stoffe, Kungliga Svenska Vetenskapsakademiens, Handlingar 24, 1-39 (1898).

[31] Y. S. Ho, G. McKay, Kinetic model for lead(II) sorption onto peat, Ads. Sci. Technol. 16, 243-255 (1998).

[32] Z. Roginsky, Ya. Zeldovich, Acta Phys. Chem. USSR 1, 554 (1934).

[33] S. H. Chien, W. R. Clayton, Application of Elovich equation to the kinetics of phosphate release and sorption on solids, Am. J. Soil Sci. Soc. 44, 265-268 (1980).

[34] C. Aharoni, S. Sideman, E. Hoffer, Adsorption of phosphate ions by colloid ioncoated alumina, $J$. Chem. Technol. Biotechnol. 29, 404-412 (1979).

[35] W. J. Weber, J. C. Morris, Kinetics of adsorption on carbon from solutions, J. Sanitary Eng. Div. ASCE 89, 31-60 (1963).

[36] Y. Kim, C. Kim, I. Choi, S. Rengraj, J. Yi, Arsenic removal using mesoporous alumina prepared via a templating method, Environ. Sci. Technol. 38, 924 931 (2004).

[37] P. Barkakati, A. Begum, M. L. Das, P. G. Rao, Adsorptive separation of Ginsenoside from aqueous solution by polymeric resins: Equilibrium, kinetic and thermodynamic studies, Chem. Eng. J. 161, 34-45 (2010).

[38] M. Alkan, O. Demirbas, M. Dogan, Removal of Acid Yellow 49 from aqueous solutions by adsorption, Fresenius Environmental Bulletin 13 (11a), 11121121 (2004). 